NBER WORKING PAPER SERIES

TRANSFORMING CITIES:

DOES URBANIZATION PROMOTE DEMOCRATIC CHANGE?

\author{
Edward L. Glaeser \\ Bryce Millett Steinberg \\ Working Paper 22860 \\ http://www.nber.org/papers/w22860 \\ NATIONAL BUREAU OF ECONOMIC RESEARCH \\ 1050 Massachusetts Avenue \\ Cambridge, MA 02138 \\ November 2016
}

Glaeser thanks the Taubman Center for State and Local Government. Three referees and an associate editor provided excellent comments. The views expressed herein are those of the authors and do not necessarily reflect the views of the National Bureau of Economic Research.

At least one co-author has disclosed a financial relationship of potential relevance for this research. Further information is available online at http://www.nber.org/papers/w22860.ack

NBER working papers are circulated for discussion and comment purposes. They have not been peer-reviewed or been subject to the review by the NBER Board of Directors that accompanies official NBER publications.

(C) 2016 by Edward L. Glaeser and Bryce Millett Steinberg. All rights reserved. Short sections of text, not to exceed two paragraphs, may be quoted without explicit permission provided that full credit, including $\odot$ notice, is given to the source. 
Transforming Cities: Does Urbanization Promote Democratic Change?

Edward L. Glaeser and Bryce Millett Steinberg

NBER Working Paper No. 22860

November 2016

JEL No. N90,O18,R00

\begin{abstract}
$\underline{\text { ABSTRACT }}$
Could urbanization lead to more democracy and better government for the mega-cities of the developing world? This paper reviews three channels through which urbanization may generate political change. First, cities facilitate coordinated public action and enhance the effectiveness of uprisings. Second, cities may increase the demand for democracy relative to dictatorship. Third, cities may engender the development of "civic capital" which enables citizens to improve their own institutions. History and empirics provide significant support for the first channel, but less evidence exists for the others. Urbanization may improve the quality of poor-world governments, but more research is needed to draw that conclusion.
\end{abstract}

Edward L. Glaeser

Department of Economics

315A Littauer Center

Harvard University

Cambridge, MA 02138

and NBER

eglaeser@harvard.edu

Bryce Millett Steinberg

Watson Institute for Int'l and Public Affairs

Brown University

111 Thayer Street

Providence, RI 02912

United States

bryce_steinberg@brown.edu 


\title{
Transforming Cities: Does Urbanization Promote Democratic Change?
}

by

\author{
Edward L. Glaeser \\ Harvard University and NBER \\ and \\ Bryce Millett Steinberg ${ }^{1}$ \\ Brown University
}

June 1, 2016

\begin{abstract}
Could urbanization lead to more democracy and better government for the megacities of the developing world? This paper reviews three channels through which urbanization may generate political change. First, cities facilitate coordinated public action and enhance the effectiveness of uprisings. Second, cities may increase the demand for democracy relative to dictatorship. Third, cities may engender the development of "civic capital" which enables citizens to improve their own institutions. History and empirics provide significant support for the first channel, but less evidence exists for the others. Urbanization may improve the quality of poor-world governments, but more research is needed to draw that conclusion.
\end{abstract}

\section{Introduction}

Massive urbanization of the poorer world inspires both awe and horror. China's spectacular post-1982 economic growth was accompanied by, and perhaps made possible

${ }^{1}$ Glaeser thanks the Taubman Center for State and Local Government. Three referees and an associate editor provided excellent comments. 
by, a 450 million-person increase in the number of Chinese urbanites. Yet the slums of Dhaka, Kinshasa and Port-au-Prince remain practically synonymous with disease, death and urban dysfunction. Will the growing cities of the developing world prove capable of promoting both future economic growth and positive political change?

This paper begins by reviewing the links between cities and economic development. Despite the growth of poor world urbanization, the cross-country link between urbanization and income is stronger than ever. Moreover, the urbanization level of poorer countries in 1960 is a potent predictor of economic growth since that time. The within-country literature on agglomeration economies typically finds that earnings increase by approximately .06 log points as density levels double, in both rich and poor countries alike (Chauvin et al., 2016).

While urban density is associated with higher incomes, contagious disease, crime, traffic congestion and high housing prices can also be features of urban life. The negative externalities that come with crowding typically require public management, but developing-world cities often have governments that are neither democratic nor competent. Poor-world cities will only become pleasant when their governments improve to the point where they can deliver clean water, public safety and reasonable commutes.

Will developing-world urbanization generate the political change that can help make developing-world cities more livable? At a purely statistical level, countries that were more urbanized in 1960 experienced more democracy after that year, holding the initial level of democracy constant. This effect is particularly strong among countries that initially had low levels of democracy. The idea that cities promote democracy is termed the "Boston Hypothesis," reflecting the seminal role that the city of Boston played in generating the American Revolution and the republic that followed.

Yet this correlation may be spurious or a side effect of rising incomes in more urbanized places. To better understand whether urbanization will improve government or promote democracy, the channels through which urban density can promote regime change are analyzed.

The paper proceeds by discussing three ways in which urbanization relates to regime change and democracy. First, urbanization may enable uprisings and revolution 
by facilitating coordination and enhancing the power of organized action. A crowd in Cairo’s Tahrir Square packs far more political punch than a group of farmers in a remote farming village. Wallace (2014) provides compelling empirical work showing that dictatorships face a far higher risk of regime change in urbanized societies.

Second, urbanization may increase the demand for democracy. To understand why populations may favor democracy or dictatorship, one can follow the framework of Djankov et al. (2003) which emphasizes that different systems offer a tradeoff between losses from overly strong governments, termed “dictatorship,” and losses from overly weak governments, termed “disorder.” Cities enable trade and facilitate innovation, both of which can be stifled by dictatorial regimes. These upsides of urban existence should push residents to favor more democracy. Yet cities also facilitate negative social interactions, including crime and the spread of contagious disease. The need to reduce those threats should increase the demand for dictatorship.

Finally, this article discusses the possibility that urbanization may promote the social skills and connections that collectively compose "civic capital": the ability of citizens to improve the quality of their government. Yet there is currently little empirical support for the view that civic capital is higher in cities.

Subsequently, the article reviews the history and empirics that are related to urbanization and democracy change. The hypothesis that cities abet revolutions against dictators seems relatively solid, supported by 26 centuries of urban revolts and Wallace's (2014) statistical work.

Empirical support for the idea that urbanization increases the demand for democracy relative to dictatorship is weaker. There are a number of important elections pitting democracy against dictatorship where urbanites voted for more democratic alternatives. Survey evidence from Latin America shows a weak correlation between urban residence and support for democracy.

The article concludes by emphasizing the need for more research on cities in the developing world, especially on the link between urbanization and governmental change.

\section{The Economic Benefits and Social Costs of Density}


The developing world is urbanizing rapidly primarily because cities typically offer tangible economic benefits. This section first discusses those benefits and then turns to the costs of urbanization. The section ends by emphasizing how the costs of density depend on the competence of the public sector.

\section{Density and Economic Opportunity}

Social scientists have been pondering the benefits of urbanization for centuries. When people and firms locate close to one another transportation costs fall (Krugman, 1991), which enhances productivity both directly and indirectly by increasing the diversity of input production (Ciccone and Hall, 1996). Adam Smith argued that urbanization enabled specialization, while in "the highlands of Scotland, every farmer must be butcher, baker and brewer for his own family.” Von Thunen emphasized the transportation cost savings in urban cores, which would then become the central agglomeration force in the new economic geography (Krugman, 1991). Alfred Marshall noted the free flow of knowledge within cities, and put forth the idea that workers can move from less productive to more productive firms in dense urban labor markets.

All of these theories suggest that workers will be more productive in cities, and most of them also suggest that wages will also be higher. ${ }^{2}$ The typical starting point for estimating agglomeration effects is an individual-level regression in which earnings are connected with metropolitan area size or density or both. From the worker's perspective, higher urban wages compensate for higher costs of living, but from the firm's perspective, higher wages must be offset by other urban advantages, typically called productivity. The marginal product of labor may be higher in cities either because workers produce more output in cities (which presumably must be true in export sectors), or because the price charged for that output is higher (which is more likely to be true for non-traded service industries).

A typical estimate from the U.S. is that the coefficient on agglomeration is about .06 , meaning that earnings increase by six percent as metropolitan area size increases by one hundred percent (Glaeser and Gottlieb, 2009). These effects are stronger for more

\footnotetext{
${ }^{2}$ One prominent exception is the Krugman (1991) model where workers are paid less because they receive the benefit of being able to buy goods cheaply.
} 
initially skilled workers, suggesting that there is a complementarity between cities and skills (Glaeser and Resseger, 2009).

Yet these ordinary least squares approaches to estimating agglomeration effects suffer from two well-known problems. First, more able workers and more productive firms may disproportionately sort in dense agglomerations. Second, some locations may be innately more productive than others and consequently attract more people. In both cases, estimated coefficients will be biased because the unobserved heterogeneity is correlated with agglomeration size and density.

Perhaps the simplest approach for improving estimation involves instrumenting for area size with past population or geography (Rosenthal and Strange, 2004, Combes et al., 2009). Another is to focus on land values, rather than earnings, because if firms are willing to pay more for land, then presumably that land brings the offsetting advantage of higher productivity (Dekle and Eaton, 1999). A third approach is to look at real wages, with or without individual fixed effects (Glaeser and Mare, 2001; Yankow, 2006; Combes et al., 2007). A final approach involves examining shocks to place, such as the opening of million-dollar plants in an area (Greenstone, Hornbeck and Moretti, 2010). This better-identified literature typically confirms that agglomeration economies are important drivers of productivity.

While most of this literature uses data from the developed world, the correlation between urban density and earnings appears to be at least as strong in the developing world (Chauvin et al., 2016), which helps explain why urbanization is increasing so quickly in the world's poorer places.

\section{Dynamics Effects of Density on Income}

Will urbanization bring dynamic benefits as well as static gains? Economics since Alfred Marshall have hypothesized that density can increase learning and the production of new ideas. Glaeser and Mare (2001) suggest that their wage evidence is compatible with the view that cities enable the formation of human capital that gradually leads to wage growth. De La Roca and Puga (2016) use administrative data from Spain to examine migrants and finds quite substantial wage growth effects in cities. 
But do cities generate wider economic growth? The correlation between income growth and initial metropolitan-area-population size is quite dependent on the time period studied. Over the 1970 to 1980 period, for example, the relationship is negative. Over the 1980 to 2000 period, the relationship is positive. Figure 1 shows the correlation across metropolitan areas with a population in 1980 that is greater than 250,000. The coefficient depicted by this figure is .03, meaning that as population doubles, income grows by approximately three percent more between 1980 and 2000. City size may predict income growth over this period because economic changes during this era were kind to cities and increasingly restrictive housing supply regulations made it difficult to move into the more productive, larger metropolitan areas.

Urbanization is also correlated with income growth across countries. Appendix Table 1 shows the basic patterns using data from the World Bank. The first two regressions show the correlation between urbanization and the logarithm of per-capita gross domestic product. ${ }^{3}$ The coefficient of 5.26 implies that a 20 percentage point increase in urbanization is associated with more than a doubling of income. In the second regression, which controls for total years of schooling and for continent, the coefficient drops to 3.5.

To examine growth effects, regression (3) relates per-capita growth between 1960 and 2010 with urbanization in 1960. The coefficient of 1.8 suggests that a ten percentage point higher urbanization rate in 1960 is associated with about 20 percent greater income growth between 1960 and 2010. Regression (4) includes controls for initial income, initial schooling and continent dummies. The coefficient is essentially unchanged.

These growth regressions do not imply that urbanization always generates growth. Omitted area-level variables may well explain this correlation. Yet the relationship is sufficiently strong that it is certainly plausible that urbanization might aid country-level growth. Cities might speed new idea formation and knowledge accumulation, especially

\footnotetext{
${ }^{3}$ Results are shown using current exchange rates. Results adjusting for purchasing power parity are quite similar.
} 
by enabling the flow of technology across continents. ${ }^{4}$ Urbanization may also promote growth by improving the quality of government.

The Downsides of Density: Negative Externalities in Cities

Agglomeration economies are significant, but the downsides of density can also be large (Glaeser, 1999). When people crowd into a dense area, they transmit diseases more easily. Urban activity can pollute both the air and the water. Proximity also enables crime, and the abundance of potential perpetrators in cities makes solving crimes more difficult (Glaeser and Sacerdote, 1999). From Medieval Paris to modern Sao Paulo, cities have sometimes become places of danger. Crowded streets make commutes longer. Building up is often more expensive than building out, which makes urban homes more expensive.

Most of these costs of density are negative externalities, which can be alleviated by effective government. Good police can reduce crime. The public sector can provide infrastructure that moves waste from city streets and brings clean water into urban centers. A substantial literature now links investment in water and sewers with public health in the U.S. (Cutler and Miller, 2005, Alsan and Goldin, 2016). Street grids and good public transportation can make traffic congestion less painful. Expensive infrastructure projects require public competence, and in the hands of a bad government, a road project becomes simply a source of corruption and patronage.

Addressing urban problems effectively often requires incentives as well as infrastructure. Singapore made its streets more valuable by using electronic road pricing to reduce congestion. The health benefits of water pipes and sewers fall if poorer people aren't willing to pay to connect to the system. Effective government can also be necessary to nudge people to connect with the infrastructure using either fines or subsidies (Ashraf, Glaeser and Ponzetto, 2016).

Consequently, the social costs of density depend on the quality of government. When the public sector is capable, as in Singapore or Sweden, infrastructure and incentives will make urban life less challenging. When the public sector is weak,

\footnotetext{
${ }^{4}$ Henderson, Jaffe and Trajtenberg (1993) document more patenting activity per capita in large cities and that patents are more likely to cite other patents that are geographically close. Audretsch and Feldman (1996) show that new product innovations are more common in large cities.
} 
urbanites will suffer more from the demons that come with density. The horrific quality of life in many developing world cities says as much about the failures of those cities’ governments as it does about the intrinsic problems of city life.

If the downsides of density are costly enough, then restricting city growth can yield benefits that are large enough to offset the losses that come from smaller agglomeration economies and eliminating the option to migrate to the city. Yet there is a possible countervailing benefit of urbanization that will be explored next. Large cities may eventually lead to better governments that make cities more livable. If urbanization yields a dividend of better government then the entire country may benefit from urbanization. The next sections discuss why urbanization might produce better government and democracy.

\section{Cities, Democratization and Government Quality}

This section explores the Boston Hypothesis - the possible link between urbanization and democracy. It first notes the empirical link between urbanization in 1960 and increases in democracy after that point. It then turns to why urbanization may actually lead to democracy, by enabling regime change, increasing the demand for democracy and building civic capital.

\section{Urbanization and the Transition to Democracy: Cross-Country Evidence}

Appendix Table 1, Panel B, examines the link across countries between urbanization in 1960 and democracy between 1960 and 2000. Regressions (1) and (2) control only for democracy in 1960 and urbanization in 1960. Regressions (3) and (4) also control for 1960 per capita GDP, education and oil production. Regressions (1) and (3) show results for all countries. Regressions (2) and (4) show results only for initially less democratic countries.

Countries that were more urbanized in 1960 have higher Polity IV democracy scores between 1960 and 2000, conditional on democracy score in 1960. This relationship holds particularly strongly for countries with low levels of democracy in 1960 (democracy index < 8). The results weaken when other characteristics are controlled for, but the coefficient on urbanization remains sizable and statistically 
significant at the 90 percent level. If income and education are partially the result of urbanization, then the results without controls may be more relevant than the results with the added controls.

While these results are hardly conclusive, they lend some credence to the idea that urbanization might be a contributing factor in any move towards democracy.

\section{Will Urbanization Promote Regime Change?}

Cities have often played a role in the toppling of dictatorial regimes. Urban proximity enables collaboration, and uprisings require people to act and plan together. As Blanksten (1960) writes, "few interests arising in rural areas are capable of making themselves heard in politics," but in cities "interest groups form more readily and give voice to the demands of urbanized sectors of the population.” A successful protest or revolution depends upon assembling enough participants, and cities make it easier to mass rebels.

Just as cities enable marriage markets (Costa and Kahn, 2000), cities enable revolutionary partnerships to emerge and grow. The partnership between John Hancock and Samuel Adams grew in pre-revolutionary Boston. Cities both lower travel costs and enable people with idiosyncratic preferences, such as the urge to topple the regime, to find each other.

In principle, urban concentration could also make it easier for dictators to monitor their own citizens. Yet while such effective surveillance may be possible in highly capable dictatorships, such as Nazi Germany or the Soviet Union at its height, such competence is beyond most modern developing world dictators. The typical despot, both today and in history, lacks the capacity to effectively patrol the hidden nooks and crannies that always exist in large cities.

Cities can also abet revolt by reducing the risks to protesters. The costs of protesting or revolting, like the costs of rioting, decline as the number of protesters increase because larger crowds make it harder for the police to target any individual protester (DiPasquale and Glaeser, 1997). Rural mobs are easy for the army to disperse or destroy. Urban mobs are harder to dislodge, partially because an abundance of urban structures make it harder for tanks and cavalry to maneuver. 
Agrarian repression occurs far from the censoring attention of the world. Protests in large cities are particularly effective when cities are highly visible to the local and global press, and when the army actually cares about avoiding opprobrium, which appears to have been the case in Cairo in 2011. Urban proximity can also increase the efficacy of an uprising, if long-term urban contact between soldiers and citizenry has increased the army's sympathy for the protesters. ${ }^{5}$

Probably the most important impact of urban size on revolutionary success occurs in capital cities, where urban protesters are close to the seat of power. Consequently, protests have more ability to threaten or disrupt the existing government. ${ }^{6}$ Even when revolution sparks in an outlying city, such as Sidi Bouzid in the Tunisian interior, governments rarely fall until the capital itself rises. President Ben Ali only left Tunisia after large protests and violence in Tunis itself.

These channels collectively make cities handmaidens to regime change, but even if a revolution starts with dreams of democracy, there are many cases, including the French and Russian Revolutions, in which an initially more democratic regime yields to a more authoritarian counter-coup. A post-revolutionary shift to democracy may not occur because the ambitions of a few may trump the desires of the many, or because postrevolution, the population might decide that authoritarianism was better than its disorderly alternative. The next section turns to the question of whether a revolution leads to democracy, and it will take the optimistic view that a democratic outcome is somewhat more likely if the benefits of democracy are larger.

\section{The Demand for Democracy}

We analyze the popular demand for democracy through the Djankov et al. (2003) framework that examines the tradeoff between dictatorship and disorder. This framework helps us understand whether urbanization will promote the “demand for democracy," which should increase the probability of revolt against a dictatorship and increase the

\footnotetext{
5 Urban interactions between Louis XVI's “French Guard” and civilians apparently increased their sympathy for protesters, which reduced the Royal ability to rout the revolutionaries with force. Prussian Kings, keenly aware of such risks, housed their army away from civilians.

6 This proximity effect may explain why dictatorships have disproportionately large capital cities, because dictators may transfer extra resources to the residents of their capitals to keep them happy, which in turn attracts more people to the capital and creates more instability for the dictator (Ades and Glaeser, 1994).
} 
probability that democracy emerges after regime. A democracy is more likely to survive after a revolution if there is widespread belief that popular sovereignty is worth a fight. Conversely, dictatorial counter-coups often need popular acceptance, which will be forthcoming when people believe that dictatorship is preferable to disorder. As Holland (1911) writes about the first Napoleon's coup “the $18^{\text {th }}$ Brumaire was nevertheless condoned, nay applauded, by the French nation," who were "weary of revolution” and "sought no more than to be wisely and firmly governed."

We now focus on the social costs of disorder and dictatorship, which shape the demand for democracy. Djankov et al. (2003) argue that different regimes create different social losses relative to an imaginary first best of perfect governance. Highly autocratic regimes that tax, extort and spend on pet projects create losses through the public sector. Djankov et al. (2003) call these public sector related costs "dictatorship.”

Yet without effective governance, ordinary thieves and armed brigands steal and destroy value. If polluters don't face regulation or Pigouvian taxes, the environment suffers. Djankov et al. (2003) collectively call the private sector costs created by weak government: "disorder."

When nations choose their constitutions, they trade dictatorship against disorder. A more empowered executive may effectively stamp out petty crime, but will also create other abuses. A limited state may avoid corruption, but fail to protect property against theft. Djankov et al. (2003) argue that countries face an Institutional Possibilities Frontier (IPF), illustrated in Figure 2, with a tradeoff between democracy and dictatorship. That paper suggests that institutions such as common law, civil law, social democracy and authoritarianism and totalitarianism represent points along that curve. Those five examples are placed moving along the curve from disorder to dictatorship.

Whenever new governments form after an uprising, countries must choose what type of government to have, which means choosing a point along that frontier. In the figure, the optimal choice of regime is illustrated by the tangency point between the Institutional Possibilities Frontier and downward sloping 45 degree line, which minimizes the sum of total social losses from dictatorship and disorder. Countries might err and choose a point above the frontier, but by assumption they cannot choose a point within the frontier. 
The form of the IPF depends on the level of economic conditions and the level of "civic capital," which refers to the social conditions, which includes both education and culture that promote effective private and public solutions to problems. This section discusses whether urbanization increases the demand for dictatorship or disorder for a given level of civic capital. The following sub-section discusses whether urbanization changes the level of civic capital.

Urbanization can lead to more democracy even if it doesn't directly increase the demand for democracy. If urbanization enables revolutions against dictators and if countries that have revolutions are likely to prefer something more democratic than the pre-revolutionary regime, then urbanization can promote democracy even if it doesn't make democracy more appealing. The existence of an uprising suggests that prerevolutionary dictatorial institutions were seen as being problematic. ${ }^{7}$ Consequently, if successful revolt topples a despot, then logically, the public will typically want more, not less democracy, and the optimal shift on the IPF is to the left.

Theory is ambiguous about cities and the demand for dictatorship. The positive interactions that can occur in cities are likely to suffer more from dictatorship, but negative urban interactions will also do more harm when governance is chaotic.

Figure 2 shows the positive case when urbanization increases the demand for democracy by increasing the scope for private sector activities. In a simple agricultural society, the losses created by an authoritarian government may be limited since choices are limited. When urbanization creates more upside potential from private interactions, including gains from trade and innovation, then the downsides of the abuse of government power increase.

This figure captures this possibility by suggesting that urbanization has shifted the Institutional Possibilities Frontier downward and flattened the curve. With a flatter curve, reducing disorder requires large losses from dictatorship. The benefits of urbanization will be reduced by an authoritarian state that imposes widespread regulation and limits private activity. ${ }^{8}$

\footnotetext{
${ }^{7}$ Moreover, if the popular sentiment was that the pre-revolutionary regime needed to be more dictatorial, then many, if not most, leaders would be happy to oblige.

${ }^{8}$ Some of the most successful modern Asian dictatorships have allowed significant economic freedom, which should reduce the demand for democracy.
} 
Yet cities also increase the scope for negative externalities. Urban density abets crime, contagious disease, and traffic congestion. Limited, democratic government makes it harder to impose the restrictions that limit these negative externalities. The strong hand of Lee Kwan Yew allowed congestion pricing in Singapore long before more democratic places charged drivers for over-using city streets. In 2016, the Philippines elected Rodrigo Duterte, a tough-talking former mayor who has promised to use any means necessary to stamp out crime and drugs-related corruption.

If negative urban externalities increase the social costs of disorder, as shown in Figure 3 , then urbanization will also increase the demand for dictatorship. This graph shows urbanization acting almost as a pure increase in the gains to dictatorship. That shift will make it less likely that uprisings end in democracy, and more likely that urbanites will support dictatorial coups that promise to rein in urban disorder.

Urbanization is more likely to increase the demand for democracy when the upsides from urban innovation are great and less likely when the costs of urban disamenities are more severe. The demand for democracy seems likely to be strong in commercial cities and weakest in industrial. Commercial cities, like the ports of America's Colonial Seaboard or the towns of Medieval Flanders, exist primarily as places of trade and exchange. Restricting freedom reduces the merchant's ability to find profits in new forms of exchange, such as importing Dutch tea into $18^{\text {th }}$ century Boston. Industrial uprisings such as the 1905 Moscow Revolution, are much more likely to focus on living conditions than freedom.

Conditions that magnify the downsides of density should decrease the demand for dictatorship. The chaotic conditions in some Middle Eastern cities, such as Cairo, may have increased the demand for strong leadership after the Arab Spring, such as the Muslim Brotherhood. Democracy may be less common in more ethnically fragmented societies (Alesina et al., 2003), because ethnically fragmented cities are typically more disorderly. ${ }^{9}$ If tropical climates increase the risks of contagious disease in cities, then the demand for dictatorship would be higher in warmer parts of the globe.

\footnotetext{
${ }^{9}$ While there are many cases in which different ethnicities peaceably co-exist in cities, ethnolinguistic fractionalization is positively correlated with murder rates (Hansmann and Quigley, 1982) and riots (DiPasquale and Glaeser, 1997).
} 
As urbanization increases the scope for positive interactions, which may be squelched by a dictatorship, and the scope for negative increases, which may be tamed by a dictator, urbanization may either increase or decrease the demand for democracy. However, even if urbanization doesn't make regime changes more likely to move towards democracy in the short run, it may still improve the quality of government by developing civic capital over time.

\section{Urbanization and Civic Capital}

Djankov et al. (2003) argue that countries can only shift the IPF downward if the level of "civic capital” increases, where civic capital represents the capacity of the country to work collaboratively to produce effective government and to produce socially beneficial outcomes even in the absence of state action. Education is one part of civic capital. Years of schooling are reliably correlated with better functioning governments, both across countries (La Porta et al., 1999) and across U.S. states (Glaeser and Saks, 2005).

Education increases the capacity of individuals to understand their governments and to work together (Glaeser, Ponzetto and Shleifer, 2007).

This sub-section discusses the hypothesis that city living may also create civic capital. Interactions are the point of urban density. Cities enable and often require people to work together with others. By collaborating, people learn how to collaborate. For example, Fossett and Kiecolt (1989) show that support for racial integration is higher in larger cities and smaller among people with farm origins. Abrahamson and Carter (1986) document a broad correlation between tolerance and city size. As Wirth (1930) famously wrote "If the individual would participate at all in the social, political, and economic life of the city, he must subordinate some of his individuality to the demands of the larger community and in that measure immerse himself in mass movements.”

Cities can enhance what Robert Putnam calls “bridging social capital,” the connectivity across different types of people, in at least two ways. First, there can just be learning by doing. By working with diverse people throughout a city, people may learn how to bridge social divides and create functional relationship despite differences in religion or ethnicity. Second, people can consciously invest in their ability to deal with 
different people in order to take advantage of the opportunities. They can learn different languages, or at least understand the idiosyncratic features of different ethnicities.

Naturally, this optimistic view of cities may not occur in reality. An urban slum can be as homogenous and isolated as a rural community. Urban political entrepreneurs can spread hatred towards an out-group in order to gain support among their own ethnicity. Still, the common Latin roots of civic, civilization and city are not accidental, for classical cities were seen as the civilizing influences that needed and produced good citizens.

\section{Suggestive Evidence on Urbanization and Democratization}

The previous section suggested that urbanization would be more likely to lead to democratization if (1) urbanization increased the probability that dictators would be toppled and dictators are typically replaced by something less dictatorial, or if (2) urbanization increased the demand for democracy. This section discusses whether history and statistics support either of these possibilities. It also discusses suggestive evidence on the link between urbanization and civic capital.

\section{Does Urbanization Promote Popular Uprisings?}

Cities have played a recurring role in revolutions throughout history, some of which were democratic. In 509 B.C., Lucius Junius Brutus gathered the people of Rome in the Forum and exhorted them to rise up against the last of the Tarquin Kings. One year later, Cleisthenes led the people of Athens against the tyrant Hippias. These urban uprisings produced the Roman Republic and Athenian democracy, which provided the classical models of non-dictatorial governments in the west. The $17^{\text {th }}$ century Dutch Republic had its roots in urban anti-Catholic riots. Urban wealth then enabled the Dutch to pay for mercenaries.

Numerous historical works (Nash, 2009, Carp, 2007) have emphasized the outsized role that cities played in fomenting the American revolt. Parisian uprisings toppled kings in 1789, 1830 and 1848. Traugott (1995) describes how "a popular insurrection in the capital was capable of bringing down the national government, virtually overnight and 
irrespective of popular sentiment in the provinces.” Dynasties were also ended by revolutions in Berlin, Lisbon and St. Petersburg. Urban uprisings also helped end the remaining communist regimes in Czechoslovakia, Poland, East Germany, Bulgaria and Romania.

In the developing world, revolutions have also often had a distinctly urban component. Democratic movements in erstwhile African colonies like Zimbabwe often began in cities (Scarnecchia, 2008). French control over Algeria was shaken by urban guerilla warfare carried on Algiers by the National Liberation Front. The People Power Revolution, largely in Manila, led to an end to the Marcos Regime. The occupation of prominent urban spaces like Tahrir Square ultimately led to the end of several authoritarian governments in the Arab Spring.

This anecdotal evidence is also supported by the empirical work of Wallace (2014), who looks at the link between urban size and the survival of non-democratic regimes. He finds that "for the 235 regimes with urban concentration levels about the mean level in the data, the mean duration is 8.6 years and the annual regime death rate is 9.1 percent," but "for the 198 regimes characterized by low levels of urban concentration, the incidence rate is only 5.7 percent and the mean duration is 12.2 years.” The impact of urbanization on regime survival is large and statistically significant, and remains effectively unchanged when he controls for a bevy of other variations. The impact of very large cities is particularly striking.

There is an older literature on revolutions and coups that finds significantly more mixed results on the link between urbanization and uprisings. Wallace's finding that "large cities are dangerous for non-democratic regimes," is at odds with studies that found that urbanization was either irrelevant or actually promoted executive stability (Auvinen, 1997). That previous work typically focused on revolutions everywhere, not just in non-democratic regimes. Since urbanites can effect political change at the ballot box in a democracy, there is far less reason for them to revolt. Consequently, one should expect big cities to lead to revolt primarily in non-democratic polities, which is exactly what Wallace finds. Our reading of this evidence is that the theoretical arguments that urbanization destabilizes autocracies, discussed above, have reasonable support in history and more modern statistical work. 


\section{Does Urbanization Increase the Demand for Democracy?}

Urban revolts may produce democracies accidentally, because anything that comes after a dictatorship is likely to be more democratic, but it is possible that urbanization actually increases the demand for democracy. Wantchekon and GarciaPonce (2016), show that African countries that experienced urban insurgency movements at the time of colonial independence are more likely to have democratic regimes today than those that experienced rural insurgencies. The authors argue that urban movements tended to involve peaceful protests, while rural movements were often based around armed conflict.

This pattern may reflect the higher costs of organizing in rural areas. Since peaceful protesters can easily be dispersed in rural areas, regime opponents need to be armed. Since the costs of armed revolt are high, revolutionaries need to be promised large tangible rewards, which can more easily be delivered by a subsequent dictatorship.

Voigtlander and Voth (2012) show that support for the Nazi Party in Germany was lower in large cities after 1928, suggesting that the demand for dictatorship was somewhat lower in urban areas. In Mexico's 2000 election that ended 71 years of oneparty rule, the opposition candidate, Vincente Fox, did far better in and around Mexico City than he did in the country as a whole. In Zimbabwe, the Movement for Democratic Change almost swept the capital city of Harare in its 2008 attempt to defeat Robert Mugabe's strongman regime, while failing to secure a national majority. ${ }^{10}$

Additional evidence on urbanization and the demand for democracy is provided by Latinobarometro, a survey of beliefs and attitudes about democracy from several countries across Latin America. Panel A of Appendix Table 2 shows the relationship between support for democracy and urban residence. In the first regression, the dependent variable equals one if respondents answered that "democracy is always the best type of government” and zero otherwise. In the next regression, the dependent variable equals one if respondents answered that "sometimes authoritarian governments are necessary," and zero otherwise. These outcomes both come from the same question and consequently

\footnotetext{
10 The Movement for Democratic Change's success in Harare is all the more remarkable considering the widespread allegations of electoral abuse.
} 
the categories are mutually exclusive. (The omitted category was "the type of government doesn’t matter.”)

Our key independent variable is an indicator variable that takes on a value of one if the respondent inhabits a city of more than 100,000 people or in the capital. The regressions control for years of education and country-fixed effects. Together, the regressions show a modest but statistically significant link with support for democracy and a negative relationship with support for autocracy. These results modestly support the hypothesis that at least in Latin America today, urbanization is positively associated with the demand for democracy.

Some additional support for the hypothesis that urbanization increases the demand for democracy is found in the urban crowds that occasionally emerge to demand democracy and to protect democracy from dictatorial subversion. In Moscow urban crowds stopped a military coup d'etat in 1991. Berliners fought against the Kapp Putsch in1920. King Gayendra's attempt to replace constitutional monarchy in Nepal with direct royal rule was thwarted by waves of protests and strikes in Kathmandu.

Hong Kong’s 2014 Umbrella Revolution was an urban movement protesting the Chinese Communist Party’s perceived interference in Hong Kong elections. The Ukrainian Orange Revolution of 2004, centered largely in Kiev, effectively reversed the rigging of a national election. The 2013 Gezi Park protests in Istanbul objected to the concentration of power by President Erdogan.

\section{Urbanization and Civic Capital}

Does urbanization actually create more civic capital? There are certainly examples of urbanites coming together to discipline rather than overthrow governments. In 1871, New Yorkers assembled in Cooper Union to organize against the rampant theft of the Tweed Ring. Twenty years later, the Progressive Era would begin as municipal reformers throughout the U.S. organized to improve the quality of city government. Nineteenth-century Paris was the hub of the global public health movement that advocated for sewers, clean water and improvements in housing quality. The Generation of 1837 was a cluster of talent in Buenos Aires that organized to promote democracy and better government in Argentina. Guatemala’s anti-corruption movement engineered a 
protest of over 100,000 people in Guatemala City and eventually forced the resignation of President Molina.

Yet there is little evidence that urbanization is positively linked with political engagement. Oliver (2000) finds that political engagement, including both voting and attending meetings, actually declines with city size within the United States. This finding supports the view that smaller jurisdictions are more accessible to citizens, but since American suburbanites are not dispersed agrarians, it does not exactly disprove the view that urbanization will promote civic capital in the developing world.

Latinobarometro data, shown in Panel B of Appendix Table 2, allows us to examine these relationships in a less developed context. A set of indicators of political engagement is regressed on a dummy for whether the respondent lives in an urban area (as described above). As in Panel A, the regressions control for education and countryfixed effects and here show only the coefficient on living in the capital city with more than 100,000 inhabitants. Urban residents are less likely to vote or work for a party or candidate, but more likely to be interested in politics or talk about politics and more likely to have participated in a protest. One interpretation of these results is that urbanites in the developing world are more likely to work for regime change but less likely to work within the system.

These existing results do not support a strong connection between urbanization and political investments at the individual level. Thomas Jefferson put more hope in the voting habits of yeomen farmers than urbanites, and perhaps he was right. Yet the existing research in this area is so limited that this article must leave the final word to future researchers.

\section{Conclusion: Mapping a Research Agenda}

The bulk of urban research has focused on the wealthy world, yet the biggest urban problems occur in the developing world. In almost every area, there is a need for significant regional research in the developing world. The most important questions continue to be the need to understand the nature of agglomeration economies and how those economies are being shaped by new technologies. 
We also need to better understand the downsides of density in the developing world. What interventions can improve housing quality cheaply in the slums of poor world mega-cities? What public health interventions can effectively improve longevity? What transportation innovations are effective at reducing hellish commutes?

This paper emphasized the role that cities can play in fomenting political change, but acknowledged that this is a hypothesis, not a fact. This paper highlighted three primary channels through which urbanization might promote democracy and good government. All three merit further investigation. Despite Wallace (2014), there is little consensus that urbanization promotes regime change among dictatorships.

The question of whether urbanization increases the demand for democracy is also unresolved. This paper presented some suggestive evidence, but since cities can also require firm management there are surely cases where urbanization increases the demand for dictatorship. In this case, it is important to map out when urbanization has made democracy more appealing and when city size has strengthened the hands of despots.

Finally, the speculative question was raised of whether urban life increases civic capital, defined as the capacity and taste for organized political action. The modest amount of existing evidence does not support this claim, yet it still seems possible to us that cities are more likely than subsistence farms to produce effective political actors. The world is rapidly urbanizing and it is necessary to better understand the widespread effects of that change.

\section{References}

Abrahamson, Mark, and Valerie J. Carter. “Tolerance, Urbanism and Region.” American Sociological Review 51, 2 (1986): 287-294.

Ades, Alberto F. and Edward L. Glaeser. "Trade and Circuses: Explaining Urban Giants.” The Quarterly Journal of Economics 110, 1 (1995): 195-227. doi:10.2307/2118515

Alesina, Alberto, Arnaud Devleeschauwer, William Easterly, Sergio Kurlat, Romain Wacziarg. "Fractionalization.” Journal of Economic Growth - Springer 8(2) (June 2003): 155-194. 
Alsan, Marcella and Claudia Goldin. "Watersheds in Infant Mortality: The Role of Effective Water and Sewerage Infrastructure, 1880 to 1915.” (NBER Working Paper No. 21263). June 2015. doi:10.3386/w21263.

Ashraf, Nava, Edward L. Glaeser and Giacomo A.M. Ponzetto. "Infrastructure, Incentives, and Institutions.” American Economic Review 106 no. 5 (May 2016): 77-82.

Auvinen, Juha. “Political Conflict in Less Developed Countries 1981-89.” Journal of Peace Research 34, 2 (1997): 177-195.

Blanksten, George I. "The Politics of Latin America.” In The Politics of The Developing Areas, edited by Gabriel A. Almond and James S. Coleman. Princeton: Princeton University Press, 1960.

Carp, Benjamin L. Rebels Rising: Cities and the American Revolution. Oxford: Oxford University Press, 2007.

Chauvin, Juan Pablo, Edward Glaeser, Yueran Ma, and Kristina Tobio. "What is Different about Urbanization in Rich and Poor Countries? Cities in Brazil, China, India and the United States.” Journal of Urban Economics (forthcoming 2016), doi: 10.1016/j.jue.2016.05.003.

Ciccone, Antonio and Robert E. Hall. "Productivity and the Density of Economic Activity.” The American Economic Review 86, no. 1 (March 1996): 54-70.

Combes, Pierre-Philippe, Gilles Duranton and Laurent Gobillon. "Spatial wage disparities: Sorting matters!” Journal of Urban Economics 63, 2 (March 2008):723-742.

Combes, Pierre-Philippe, Gilles Duranton, Laurent Gobillon and Sébastien Roux. "Estimating Agglomeration Economies with History, Geology, and Worker Effects." In Agglomeration Economics, edited by Edward L. Glaeser, 15-66. Chicago: University of Chicago Press, 2010.

Costa, Dora L. and Matthew E. Kahn. "Power Couples: Changes in the Locational Choice of the College Educated.” The Quarterly Journal of Economics 115, 4 (2000): 1287-1315.

Cutler, David M. and Edward L. Glaeser. “Are Ghettos Good or Bad?” The Quarterly Journal of Economics 112, 3 (1997): 827-872.

Cutler, David M. and Grant Miller. "The Role of Public Health Improvements in Health Advances: The Twentieth-Century United States.” Demography 42, 1 (February 2005): $1-22$. 
Damm, Anna Piil. "Ethnic Enclaves and Immigrant Labor Market Outcomes: QuasiExperimental Evidence.” Journal of Labor Economics. 27, 2 (April 2009): 281-314.

De La Roca, Jorge and Diego Puga. “Learning by Working in Big Cities.” Review of Economic Studies, forthcoming.

Dekle, Robert and Jonathan Eaton. "Agglomeration and Land Rents: Evidence from the Prefectures.” Journal of Urban Economics 46, 2 (1999): 200-214.

DiPasquale, Denise and Edward L. Glaeser. "The Los Angeles Riot and the Economics of Urban Unrest.” Journal of Urban Economics 43, 1 (1998): 52-78.

Djankov, Simeon, Edward Glaeser, Rafael La Porta, Florencio Lopez-de-Silanes and Andrei Shleifer. “The New Comparative Economics.” Journal of comparative Economics 31, 4 (2003): 595-619.

Duranton, Gilles and Matthew A. Turner. "Fundamental Law of Road Congestion: Evidence from US Cities.” American Economic Review 101, 6 (2013): 2616-2652.

Feldman, Maryann P. “Location and Innovation: The New Economic Geography of Innovation, Spillovers, and Agglomeration.” In The Oxford Handbook of Economic Geography, edited by Gordon L. Clark, Meric S. Gertler, and Maryann P. Feldman. 373394. Oxford: Oxford University Press, 2000.

Fossett, Mark A., and Kiecolt K. Jill. "The Relative Size of Minority Populations and White Racial Attitudes.” Social Science Quarterly 70, 4 (1989): 820-835.

Glaeser, Edward L. “Are Cities Dying?” Journal of Economic Perspectives 12, 2 (1998): 138-160. doi: 10.1257/jep.12.2.139.

Glaeser, Edward L. and Bruce Sacerdote. "Why Is There More Crime in Cities?” Journal of Political Economy 107, S6 (1999): S225-S258.

Glaeser, Edward L. and Joshua D. Gottlieb. "The Wealth of Cities: Agglomeration Economies and Spatial Equilibrium in the United States.” Journal of Economic Literature 47, 4 (2009): 983-1028.

Glaeser, Edward L. and David C. Mare. “Cities and Skills.” Journal of Labor Economics 19, 2 (2001): 316-342.

Glaeser, Edward L., and Raven E. Saks. “Corruption in America.” Journal of public Economics 90, 6 (2006): 1053-1072.

Glaeser, Edward L., Giacomo A.M. Ponzetto and Andrei Shleifer. "Why Does Democracy Need Education?” Journal of Economic Growth 12 (2007): 77-99. 
Glaeser, Edward L. and Matthew G. Resseger. “The Complementarity Between Cities and Skills.” Journal of Regional Science 50, 1 (2010): 221-244.

Greenstone, Michael, Richard Hornbeck and Enrico Moretti. "Identifying Agglomeration Spillovers: Evidence from Winners and Losers of Large Plant Openings.” Journal of Political Economy 18, 3 (2010): 409-432.

Hansmann, Henry B., and John M. Quigley. "Population Heterogeneity and the Sociogenesis of Homicide.” Social Forces 61, 1 (1982): 206-224.

Holland, Arthur William (1911). "French Revolution.” In Chisholm, Hugh. Encyclopæedia Britannica (11th ed.). Cambridge: Cambridge University Press.

Jaffe, Adam B., Manuel Trajtenberg and Rebecca Henderson. "Geographic Localization of Knowledge Spillovers as Evidenced by Patent Citations.” The Quarterly Journal of Economics 108, 3 (1993): 577-598.

Krugman, Paul. “Increasing Returns and Economic Geography.” Journal of Political Economy 99, 3: 460-482.

La Porta, Rafael, Florencio Lopez-de-Silanes, Andrei Shleifer and Robert Vishny. "The Quality of Government.” Journal of Law, Economics, \& Organization 15, 1 (1999): 222279.

Nash, Gary B. The Urban Crucible: The Northern Seaports and the Origins of the American Revolution (abridged edition). Cambridge: Harvard University Press, 2009.

Oliver, J. Eric. “City Size and Civic Involvement in Metropolitan America.” American Political Science Review 94, 2 (2000): 361-373.

Rosenthal, Stuart S. and William C. Strange. "Evidence on the Nature and Sources of Agglomeration Economies.” Handbook of Regional and Urban Economics 4 (2004): 2119-2171.

Scarnecchia, Timothy. The Urban Roots of Democracy and Political Violence in Zimbabwe: Harare and Highfield, 1940-1964. Vol. 35. Rochester: University of Rochester Press, 2008.

Traugott, Mark. “Capital Cities and Revolution.” Social Science History 19, 1 (1995): 147-168.

Voigtländer, Nico, and Hans-Joachim Voth. "Persecution Perpetuated: The Medieval Origins of Anti-Semitic Violence in Nazi Germany.” Quarterly Journal of Economics 127, 3 (2012): 1339-1392. 
Wallace, Jeremy. Cities and stability: urbanization, redistribution, and regime survival in China. Oxford: Oxford University Press, 2014.

Wantchekon, Leonard and Omar Garcia-Ponce, “Critical Junctures: Independence Movements and Democracy in Africa,” 2016, mimeo.

http://wrap.warwick.ac.uk/id/eprint/59346

Wirth, Louis. “Urbanism as a Way of Life.” American Journal of Sociology 44, 1 (1938): $1-24$.

Yankow, Jeffrey J. "Why Do Cities Pay More? An Empirical Examination of Some Competing Theories of the Urban Wage Premium.” Journal of Urban Economics 60, 2 (2006): 139-161. 
Figure 1: Metropolitan Area Size and Income Growth 1980-2000

Change in Income 1980-2000

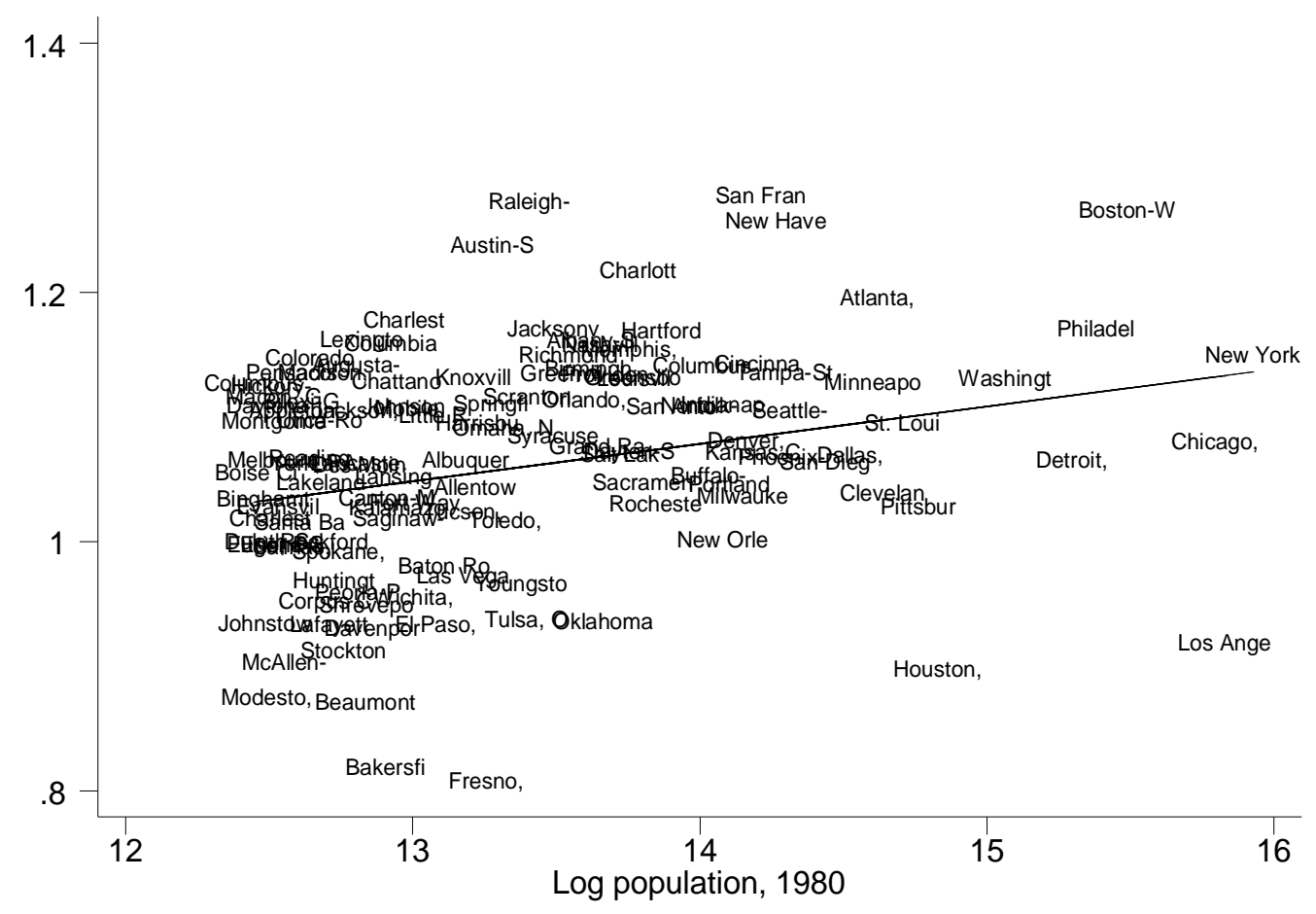

Note: This figure is based on U.S. Census data on metropolitan-area incomes from 1980 to 2000 and metropolitan-area population in 1980. Metropolitan areas have been adjusted to have constant borders. 
Figure 2: The Institutional Possibilities Frontier and Development

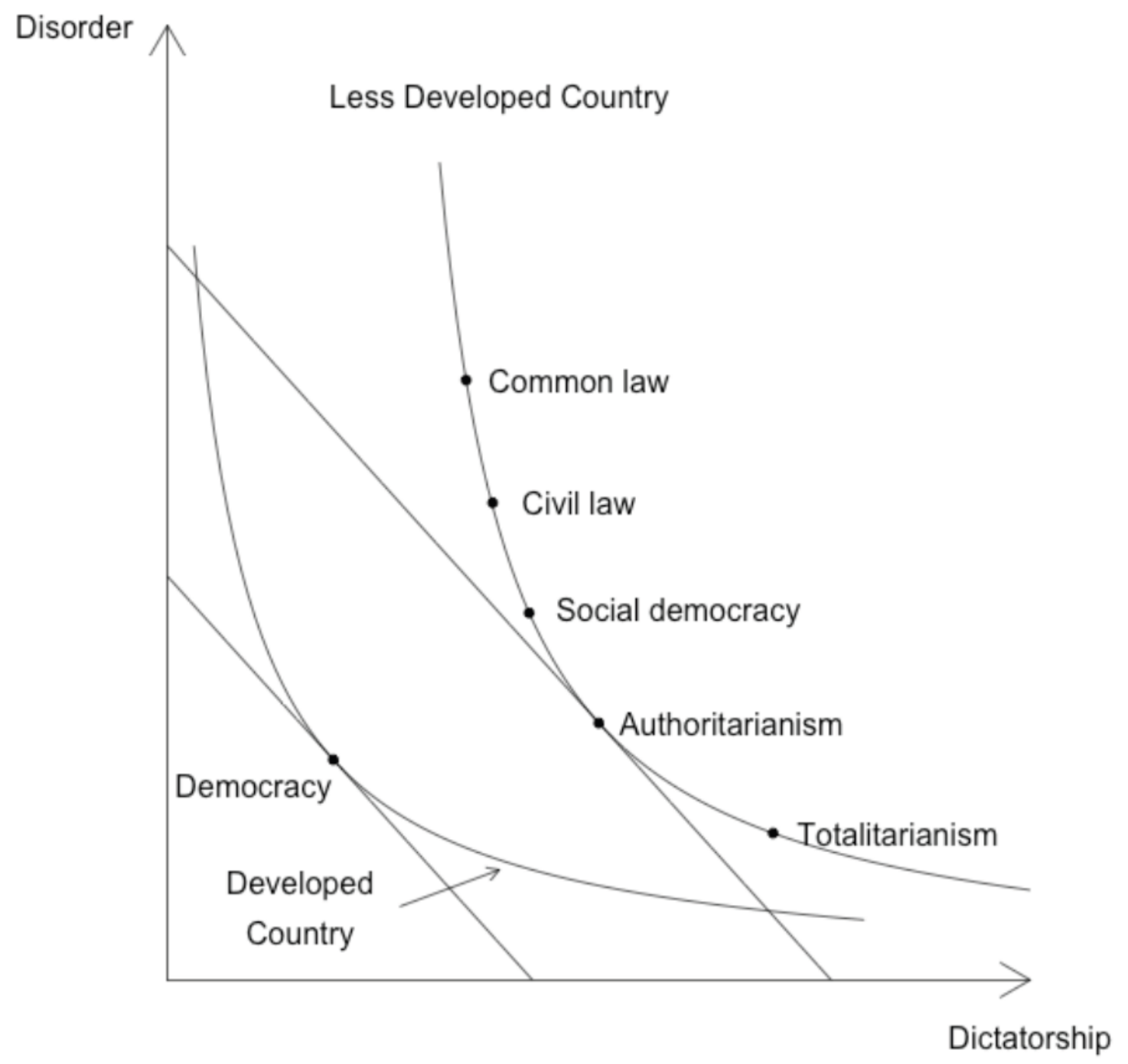

Figure 3: The Institutional Possibilities Frontier and Urban Externalities 


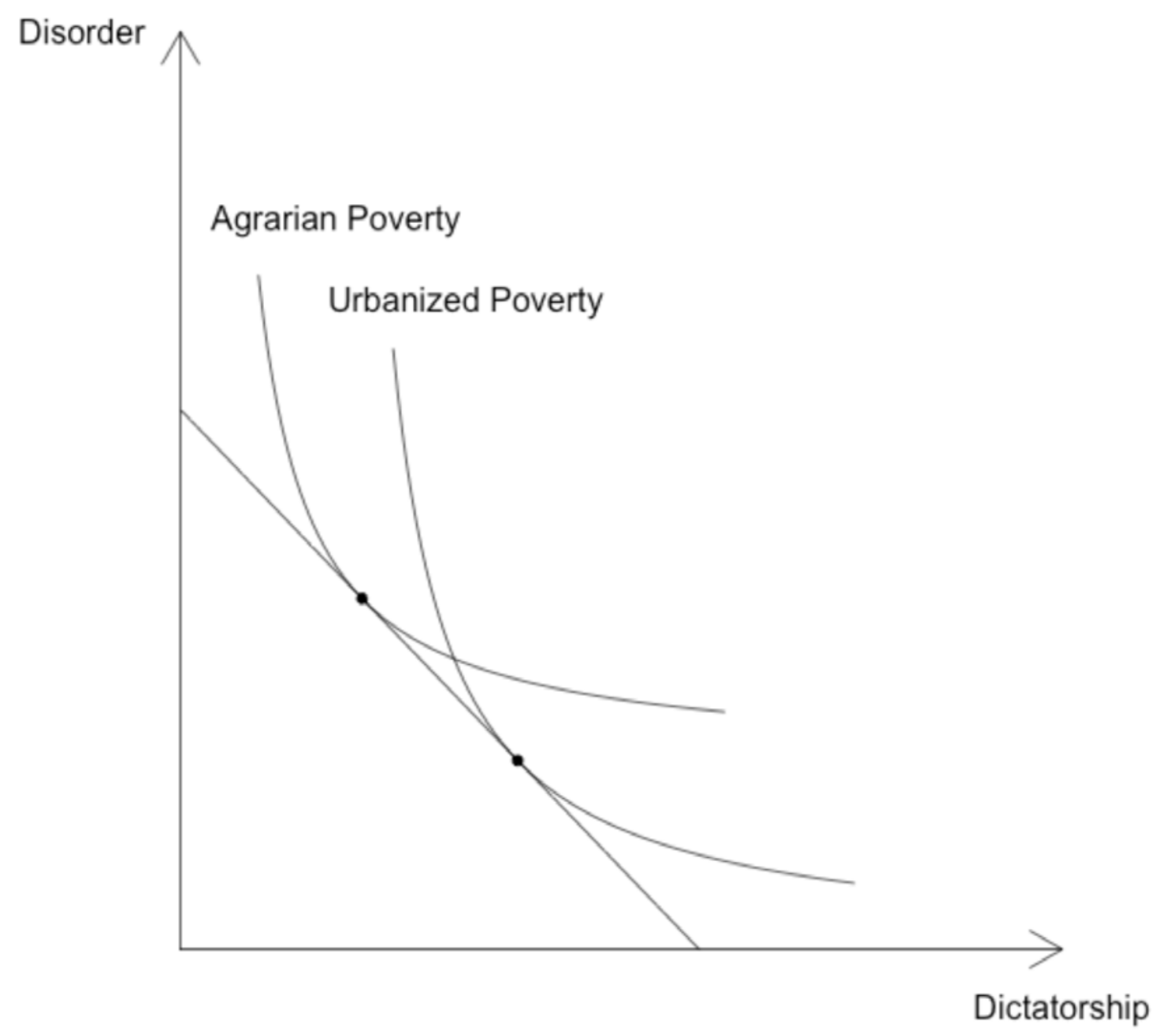




\section{Appendix Table 1: Cross-Country Evidence on Urbanization, GDP Growth, and Democracy}

\begin{tabular}{|c|c|c|c|c|}
\hline \multicolumn{5}{|c|}{ Panel A: Urbanization and GDP Growth } \\
\hline Dependent Variable: & \multicolumn{2}{|c|}{$\log (2010$ GDP) } & \multicolumn{2}{|c|}{ GDP Growth 1960-2010 } \\
\hline & (1) & (2) & (3) & $(4)$ \\
\hline Urbanization in 1960 & $\begin{array}{c}5.26^{* * *} \\
(.34)\end{array}$ & $\begin{array}{c}3.53 * * * \\
(.34)\end{array}$ & $\begin{array}{c}1.89 * * * \\
(.34)\end{array}$ & $\begin{array}{c}1.79 * * * \\
(.62)\end{array}$ \\
\hline Schooling in 1960 & & $\begin{array}{l}.18 * * * \\
(.034)\end{array}$ & & $\begin{array}{l}.14^{* *} \\
(.058)\end{array}$ \\
\hline $\log (1960$ GDP) & & & & $\begin{array}{c}-.56 * * * \\
(.18)\end{array}$ \\
\hline Observations & 141 & 141 & 93 & 93 \\
\hline R-Squared & .63 & .78 & .25 & .40 \\
\hline Continent Fes & No & Yes & No & Yes \\
\hline \multicolumn{5}{|c|}{ Panel B: Urbanization and Democracy } \\
\hline & \multicolumn{4}{|c|}{ Dependent Variable: Democracy Index, 1960-2000 } \\
\hline & $(1)$ & $(2)$ & (3) & $(4)$ \\
\hline Urbanization in 1960 & $\begin{array}{c}4.39 * * \\
(1.96)\end{array}$ & $\begin{array}{c}9.01 * * * \\
(2.81)\end{array}$ & $\begin{array}{c}2.50 \\
(2.11)\end{array}$ & $\begin{array}{l}6.01^{*} \\
(3.50)\end{array}$ \\
\hline Democracy in 1960 & $\begin{array}{l}.25^{* *} \\
(.10)\end{array}$ & $\begin{array}{l}-.017 \\
(.19)\end{array}$ & $\begin{array}{c}.12 \\
(.094)\end{array}$ & $\begin{array}{l}-.014 \\
(.163)\end{array}$ \\
\hline Observations & 79 & 55 & 53 & 32 \\
\hline Controls & No & No & Yes & Yes \\
\hline Democracy $<8$ in 1960 & No & Yes & No & Yes \\
\hline \multicolumn{5}{|c|}{$\begin{array}{l}\text { Source: World Bank } \\
\text { Notes: Panel A of this table shows coefficients from an OLS regression of the natural log of } 2010 \text { GDP } \\
\text { (columns } 1 \text { and 2) and GDP growth (columns } 3 \text { and 4) on urbanization in 1960. GDP is converted to USD } \\
\text { at current exchange rates. Columns } 2 \text { and } 4 \text { also control for average years of schooling in } 1960 \text {, and column } \\
4 \text { also controls for the log of } 1960 \text { GDP. Standard errors are reported in parentheses. Panel B of this table } \\
\text { shows coefficients from an OLS regression of the index of democracy from } 1960-2000 \text { on urbanization in } \\
1960 \text {. Democracy index ranges from } 1-10 \text {. Columns } 1 \text { and } 3 \text { include all countries for which the data exists. } \\
\text { Columns } 2 \text { and } 4 \text { restrict to those countries with lower democracy ex-ante (index }<8 \text { ). Columns } 3 \text { and } 4 \text { also } \\
\text { include controls for years of schooling in } 1960 \text {, the logarithm of per capita GDP in } 1960 \text { and the logarithm } \\
\text { of per capita oil production. *significant at } 10 \% * * \text { significant at } 5 \% * * * \text { significant at } 1 \% \text {. }\end{array}$} \\
\hline
\end{tabular}




\section{Appendix Table 2: Urbanization and Pro-Democracy Sentiment and Engagement}

\begin{tabular}{|c|c|c|c|c|}
\hline \multicolumn{5}{|c|}{ Panel A: Pro-Democracy Attitudes } \\
\hline \multirow[t]{2}{*}{ Dependent Variable: } & Pro-Democracy & \multicolumn{3}{|c|}{ Pro-Authoritarian } \\
\hline & $(1)$ & \multicolumn{3}{|c|}{$(2)$} \\
\hline Urban & \multicolumn{2}{|l|}{$\begin{array}{l}.018 * * \\
(.0058)\end{array}$} & \multicolumn{2}{|c|}{$\begin{array}{l}-.018 * * \\
(.0073)\end{array}$} \\
\hline Observations & \multicolumn{2}{|l|}{18,685} & \multicolumn{2}{|c|}{18,685} \\
\hline \multicolumn{5}{|c|}{ Panel B: Political Engagement } \\
\hline & Urban & Std. Err & Obs. & Rural Mean \\
\hline \multicolumn{5}{|l|}{ Dependent Variable: } \\
\hline Interested in politics & $.0087 * *$ & .0036 & 19,939 & .484 \\
\hline Voted in last election & $-.028 * * *$ & .0062 & 19,966 & .750 \\
\hline \multicolumn{5}{|l|}{ How frequently... } \\
\hline talk about politics with friends & $.0084 * *$ & .0033 & 20,051 & 461 \\
\hline work for party or candidate & $-.0081 * * *$ & .0026 & 20,000 & .349 \\
\hline try to persuade others to vote & .0012 & .0029 & 19,939 & .364 \\
\hline \multicolumn{5}{|l|}{ Have ever... } \\
\hline signed a petition & -.0030 & .0070 & 19,841 & .334 \\
\hline attended a protest & $.0128 * *$ & .0064 & 19,850 & .233 \\
\hline refused to pay taxes & .0048 & .0039 & 19,587 & .069 \\
\hline used force/violence for pol. cause & .00057 & .0032 & 19,687 & .045 \\
\hline
\end{tabular}

Source: Latinobarometro, 2013

Notes: Panel A of this table shows coefficients from an OLS regression of attitudes toward democracy and authoritarianism on city size. In column 1, the dependent variable is equal to 1 if the respondent answered that democracy is always the best form of government, and 0 otherwise. In column 2, the dependent variable is equal to one if the respondent answered that sometimes authoritarian governments are necessary, and 0 otherwise. These answers were mutually exclusive, and the omitted category was that it doesn't matter. In all panels, the independent variable is equal to 1 if the respondent lives in a city with at least 100,000 people or in the capital. All regressions control for country-level fixed effects and respondent education.

Standard errors are reported in parentheses in panel A, and in column 2 of Panel B. *significant at $10 \%$ **significant at $5 \%$

$* * *$ significant at $1 \%$. 